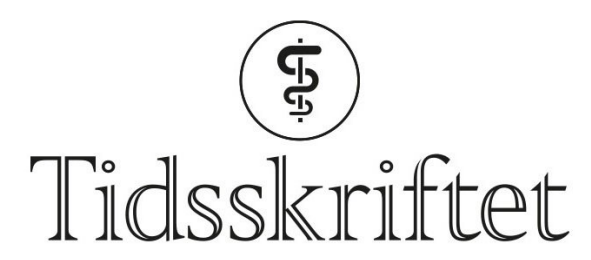

DEN NORSKE LEGEFORENING

\title{
Liten effekt av universell testing og behandling for hiv i Afrika
}

FRA ANDRE TIDSSKRIFTER

\section{KRISTOFFER BRODWALL}

E-post: kristoffer.brodwall@gmail.com

Barne- og ungdomsklinikken

Haukeland universitetssjukehus

Antiretroviral behandling av alle hivpositive uavhengig av $\mathrm{CD}_{4}$-tall reduserer virusmengden, men reduserer ikke forekomsten av nye hivsmittede personer.

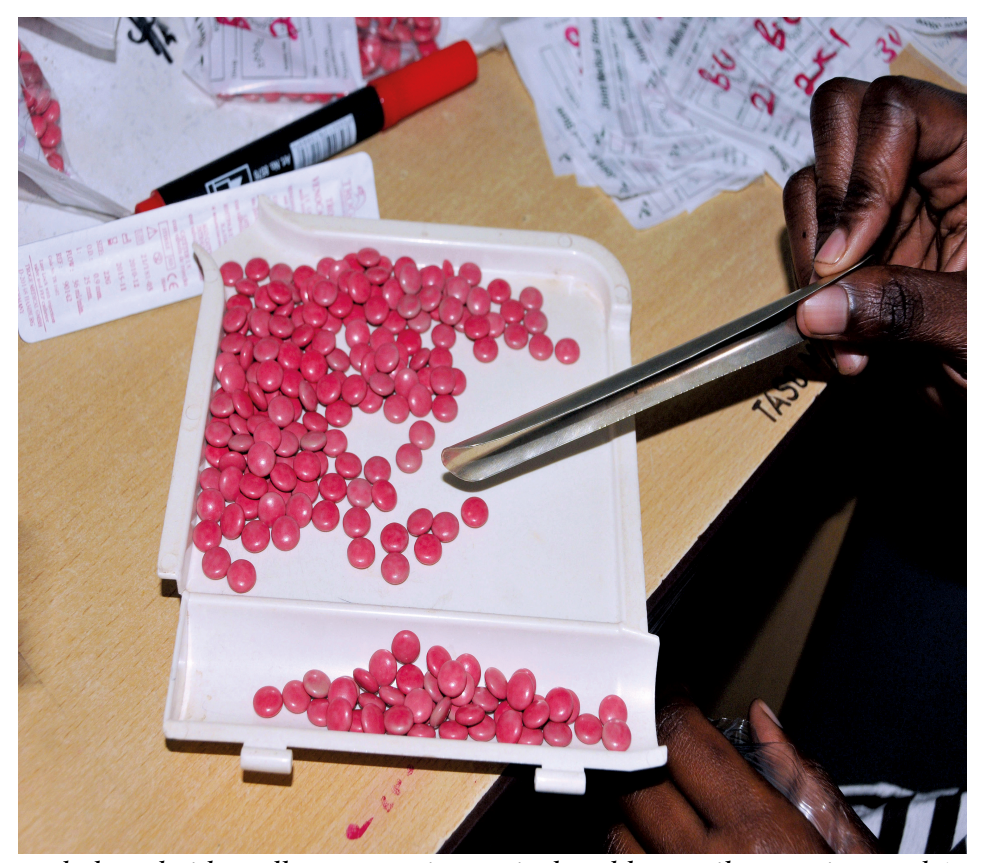

En helsearbeider teller opp antiretrovirale tabletter til en pasient ved AIDS Support Organization (TASO) i Ugandas hovedstad Kampala. Illustrasjonsfoto: Stephen Wandera / NTB Scanpix

Den globale forekomsten av hiv er nedadgående, men fremdeles lever omkring 37 millioner mennesker med viruset og ca. 1,8 millioner blir smittet hvert år. Det er derfor behov for ytterligere tiltak. I tre nylig publiserte studier fra høyendemiske områder i Afrika har man vurdert regelmessig testing for hivinfeksjon og antiretroviral behandling av alle hivinfiserte uavhengig av CD4-tall, såkalt universell behandling (1-3).

I den ene studien ble 32 distrikter i Uganda og Kenya randomisert til årlig hivtesting og universell antiretroviral behandling eller standard oppfølging i fire år (1). Av rundt 150 ooo personer var ca. 10 \% hivpositive. Årlig hivinsidens sank fra 0,43 til o,31 per 100 personår 
$\mathrm{i}$ intervensjonsgruppen, men kumulativ insidens var ikke signifikant lavere enn i kontrollgruppen.

I den andre studien ble 30 distrikter i Botswana randomisert til hivtesting, veiledning og antiretroviral behandling og omskjæring av menn eller standard oppfølging i fem år (2). Av rundt 12600 personer var ca. $29 \%$ hivpositive. 57 personer i intervensjonsgruppen og 9o personer i kontrollgruppen ble hivsmittet. Forskjellen var ikke statistisk signifikant.

I den tredje studien ble 21 distrikter i Zambia og Sør-Afrika randomisert til enten forebyggende tiltak og universell antiretroviral behandling, eller forebyggende tiltak og antiretroviral behandling etter lokale retningslinjer, eller standard oppfølging i fem år (3). Av rundt 48300 personer var ca. $21 \%$ hivpositive. I løpet av studieperioden ble 553 personer hivsmittet. Insidensen av hivinfeksjon var lavere i de to intervensjonsgruppene enn i kontrollgruppen, men statistisk signifikant bare for gruppen som fikk antiretroviral behandling etter lokale retningslinjer.

Studiene viste altså ikke den forventede effekten av universell antiretroviral behandling på antall nysmittede, hvilket blir diskutert i en ledsagende kommentar (4). Noe av forklaringen kan være at standardbehandling beveger seg i retning av intervensjonen $\mathrm{i}$ studiene, dvs. stadig tidligere oppstart av antiretroviral behandling. Videre kan personer ha blitt smittet fra noen som bor utenfor samme distrikt som dem. Dessuten kan enkeltpersoner ha ført smitten videre før hivtesten var positiv.

\section{LITTERATUR:}

1. Havlir DV, Balzer LB, Charlebois ED et al. HIV testing and treatment with the use of a community health approach in rural Africa. N Engl J Med 2019;381: 219-29. [PubMed][CrossRef]

2. Makhema J, Wirth KE, Pretorius Holme M et al. Universal testing, expanded treatment, and incidence of HIV infection in Botswana. N Engl J Med 2019; 381: 230-42. [PubMed][CrossRef]

3. Hayes RJ, Donnell D, Floyd S et al. Effect of universal testing and treatment on HIV incidence - HPTN o71 (PopART). N Engl J Med 2019; 381: 207-18. [PubMed][CrossRef]

4. Abdool Karim SS. HIV-1 Epidemic Control - Insights from Test-and-Treat Trials. N Engl J Med 2019; 381 : 286-8. [PubMed][CrossRef]

Publisert: 20. september 2019. Tidsskr Nor Legeforen. DOI: 10.4045/tidsskr.19.0484

(C) Tidsskrift for Den norske legeforening 2020. Lastet ned fra tidsskriftet.no 